2018 Seifert, R., \& Wang, W., The moderating role of trade unions in embedding equality at work practices: a case study of five English local authorities, Industrial Relations Journal, DOI: 10.1111/irj.12214 , CABS 3*, forthcoming

\title{
Race discrimination at work: the moderating role of trade unionism in English Local government
}

\begin{abstract}
Racism in the workplace remains a serious issue in the UK. Despite over forty years of legislation and regulation alongside a raft of HRM policy initiatives, there remains limited research on the differences in employment experience of BAME staff (Black, Asian, and Minority Ethnic) and their white colleagues. This paper recognises the nature of the power imbalance at work as between individual employees and management, traditionally disadvantaged group (ethnic minority) and the dominant work group. This lack of equity was counterbalanced by strong workplace trade unionism in the past, but such countervailing forces have been hit and miss in their operation. In particular, we know little about the role of trade unionism on the perception of workplace equality among BAME employees. Using more than 2580 valid responses from full-time employees in highly unionised and wellregulated five English local government councils, this study shows that BAME employees have a significant lower evaluation than their white colleague of fair pay and equal work environment (management endeavour to prevent discrimination, bullying, and racism). The latter, an equal work environment, fully mediates the negative perception between BAME staff and fair pay; with the same level of equal work environment perception, BAME employees have a significantly higher job satisfaction than their white colleagues. Furthermore, the perception of union commitment to equality strengthened their views of a management-supported equal work environment.
\end{abstract}

Key words: BAME, Perceptions of trade unions, Equal work environment, fair pay, job satisfaction 


\section{Introduction}

Employees perform better, carry out their allotted tasks to the required standard, if they are more, rather than less satisfied with their general work experience. This includes, inter alia, pay, conditions of service (Charness and Kuhn, 2007), and some nominal dignity at work (free from bullying and discrimination; Hodson 2001). Our central focus relates to the employment experience of a traditionally disadvantaged group, British Black and Asian Minority Ethnic staff (BAME) in the public sector. Their 'disadvantage' has been in part due to persistent and widespread race discrimination at work in the UK (Dickens 2007). One manifestation of this is the extraordinary existence of a substantial pay gap based on ethnicity (Chowdhury 2016; Lewis and Gunn 2007). Such discrimination has persisted despite over forty years of legislation and regulation since 1976 Race Relations Act, and a raft of HRM policy initiatives in this area.

Deeply embedded race discrimination requires efforts from the government through legislation, and other parties' involvement to uproot it (Hoel, 2013). Most measures taken so far tend to be top-down initiatives based on unitarist ideology (government and CIPD reports), which ignore the power imbalance between individual employees and employers (Hyman 1994). Consequently, the role of trade unions has been underplayed and under-researched, although all mainstream UK unions today have robust anti-racist and anti-racism policies and programmes, BAME members remain underrepresented at workplace level compared with their proportion in the population (TUC 2014,p3). As a result, the debate inside unions has been narrowly focused on access to work rather than experiences of work (TUC, 2017). The daily reality of racism at work for many British BAME workers has been relatively neglected.

We aim to contribute to the debate in two ways by examining BAME workers' employment experiences. First, we explore the mechanism of perceived management commitment to an equal work environment on the relationship between BAME and their evaluation of pay and job satisfaction, against persistent racism at work. This will help to address the recruitment challenges faced by the public sector due to relatively low pay (Chynoweth, 2015). Second, we examine the moderating effect of equality-committed trade unionism on perceived management efforts to maintain an equal work environment through the "shock effect" on managers by trade union activity. This is derived from two important dimensions of trade unions in their relationship with BAME workers: as policy makers and opinion formers (Miles \& Phizacklea 1978; Fitzgerald \& Stirling 2004; TUC 2015a); and as representatives in negotiations with employers (ACAS 2014; Archibong and Darr 2010). It then expands the debate of trade unions' position towards their BAME members. In order to do so, we collected 2580 valid responses from 15,000 questionnaires attained from five English local councils. ${ }^{1}$ In the sections that follow, we reviewed BAME employees in the public sector and the role of trade

\footnotetext{
${ }^{1}$ This survey was funded by UNISON
} 
unionism to ensure equality implementation, this leads to our testable hypotheses. We employed Structural Equation Modelling to analyse the data. Based on empirical outcomes, a discussion was offered, and followed by the conclusion.

\section{BAME at work}

The importance of unlocking BAME workers' talents has been illustrated in a recent governmentsponsored review led by Baroness Ruby McGregor-Smith (McGregor-Smith 2017). It argues that fair access to employment for BAME workers can boost the UK economy by $£ 24$ billion a year $(1.3 \%$ of the GDP). She also rightly pointed out the systematic and institutionalised discrimination towards BAME workers that prevents such a contribution from being attained. Most studies and policy interventions echo this line of debate: that long-standing inequality in accessing employment has disadvantages for all those involved (Virdee 2006; UNITE bulletin October 2016). However, academic studies of BAME workers and their general attitudes to work are few and far between. Lewis and Gunn (2007) reported that BAME staff in the public sector experienced widespread discrimination, bullying, and harassment from their line managers and colleagues, and this was compounded by discrimination towards ethnic minority workers from service-users (Wood et al. 2013). Ethnicity tends to lead to social exclusion at work as evidenced, for example, in the emergency services (Owoyemi and Sheehan, 2011).

Trade unions have been more willing to 'out' the existence of discrimination towards their BAME members. In Higher Education, for example, BAME staff complains of unfairly receiving poor appraisals and of having been overlooked for promotion (ECU 2009, p29). In the NHS, Archibong and Darr (2010) found that BAME doctors are more likely to be referred to the GMC and to be on long-term suspension than their white counterparts. Similar discriminative behaviour exists within nursing -- nurses from black and minority ethnic backgrounds are overrepresented in employment relations' cases and referrals to the nursing regulator compared with their white colleagues (Nursing Standard, January 2014). A Unite snapshot survey of its BAME members revealed a lack of promotion, racial harassment, and bullying (UNITE bulletin October 2016).

In local government there remain cases in which management failings appear to be total. UNISON (2017) revealed that race discrimination can deepen the impact of problems of pay, promotion, and training for its BAME members. A recent report, for example, shows that BAME employees were paid up to $37.5 \%$ less than their white colleagues in the public sector in London (Bulman and Musaddique 2018). This corresponds with other studies (Lewis and Gunn, 2007; Wood et al., 2013) and suggests the hypotheses that, ceteris paribus, BAME employees have more negative perceptions than their white colleagues of two key aspects of work: pay and satisfaction

Hypothesis 1a: BAME employees in local government are negatively related to the perceptions of fair pay 
Hypothesis 1b: BAME employees in local government are negatively related to job satisfaction

The power imbalance in the employment relationship between individual employees and their employer is recognised in both laws relating to worker's rights and the raft of HRM policies aimed at preventing arbitrary management decisions. There would appear, therefore to be a set of duties and obligations on managers to prevent racism and bullying towards this traditionally disadvantaged group, BAME staff. Unfortunately, some of managers were found to be the penetrators themselves. In the Brent Council case, the HR director was found guilty of victimising and discriminating against a black worker (Brent and Kilburn Times, 22/9/2014). Such 'institutional' racism can be rooted in the culture of senior management teams. Pate et al. (2012) reported that senior management admitted failing to previously acknowledge bullying and act on it despite the presence of a no-bullying policy. Consequently, high levels of perceived bullying were reported among employees and only were significantly reduced when several senior managers were dismissed, as a result of being found guilty of bullying. On the other hand, the primary concern of HR managers appears to be organisational outcomes and leads to the negligent attitude towards reported racism, bullying, and discrimination. According to Harrington et al. (2012), there exists a wide spread belief among HR managers that accusations of bullying were excessively used to disguise a performance-management issue of the likely guilty party, and managers frequently suggest, for example, that BAME workers play the 'race card' when their own behaviour and/or performance is questioned (Jefferys 2015).

Subsequently, the processes for a grievance were seen by employees as lengthy and biased in favour of managers (Harrington et al., 2012). Unsurprisingly, a lack of trust in HR as being able and willing to enact the equality policy in a fair and timely manner was attributed to victims not filing a complaint (UNISON, 2009). This echoes the 'head in sand' mentality to equality and diversity policy in many organisations reported by ACAS (2006 p21) a decade ago. This leads to our hypothesis 2

Hypothesis 2: BAME employees in local government are negatively related to the perception of an equal work environment

As noted in extant studies, discrimination is deep rooted in society, BAME staff were found bullied by line managers, colleagues from the dominant work group and service-users (Lewis and Gunn, 2007; Wood et al., 2013). Against such persistent bullying and racism, managers have the superior power at workplace to stop such negative behaviour and to nurture a positive equal work environment, we propose that BAME employees who feel that management made genuine efforts to sustain an equal work environment (prevention of racism, discrimination and bullying) are more likely to believe they were paid fairly; and more likely to have a higher job satisfaction than their white colleagues. This leads to our hypothesis 3 
Hypothesis 3a: The relationship between BAME and fair pay is mediated by an equal work environment

Hypothesis 3b: The relationship between BAME and job satisfaction is mediated by an equal work environment

One main argument to explain the failure to enforce BAME equality measures is utilitarian in nature and rooted in the rational employer thesis that states the benefits to the firm from such policies outweigh the costs. This is well illustrated by McGregor-Smith (2017) that it is in the employer's interest to treat BAME employees fairly, but the solution she proposed is to bring the disproportionally representation of BAME workers into the daylight. This is the same as the barriers and solution identified a decade ago by ACAS (ACAS 2006 p21): lack of awareness, entrenched attitudes, embarrassment, 'head in the sand' mentality - to more organisational barriers such as the absence of clear lines of responsibility. This is unlikely to work as evidenced by a range of reported cases in which the management stated that 'we have learned from our mistakes' and 'we are disappointed with our performance' and 'we do not recognise ourselves in these cases', phrases commonly applied by senior managers to bad outcomes when they are publicised.

Neither recent government reports nor ACAS advice sees unions as part of the solution. This is partly because the power imbalance between individual employees, especially when members of a traditionally disadvantaged group and their employer is ignored in such discourses. We argue that trade unions are a major part of the process and can help to secure a more effective and constructive set of solutions. Trade unions have traditionally had four dimensions with their relationship with BAME workers in the UK: policy makers and opinion formers; representatives of BAME workers (Fevre 1985, Virdee and Grint 1994, Humphrey 2000, Wrench 2000, Virdee 2000, Holgate 2004a); embracing equality; and work within the BAME community (Lucio and Perret 2009). The first two dimensions were well explained by Wrench (1986, p.1): trade unions are more decisive than any other parties in the struggle to uproot racist prejudice, check racist discrimination, and help the country to achieve true equal opportunities in jobs, promotion, education, housing and the whole of the social services. This is carried out through two broad activities: "Firstly, trade unions have an essential role to play in the promotion of racial equality in workplace negotiations with employers. Secondly, within their own organisations themselves, trade unions must be seen to be embracing the equal opportunity and anti-racism, both in the treatment of a union's own employees, and in the organisation and servicing of its own membership, (an activity which must include tackling racism amongst union members)".

The role of trade unions was examined as the main vehicle through which equality is implemented at work, in terms of the 'shock' proposition (Mefford 1986, Verma 2005), namely that union pressure 
can 'shock' managers into being better at enforcing and sustaining their own policies at work, including those on race equality. This 'shock-effect' has been debated in relation to productivity increases although the extent to which this 'shock' lasts has been contested (Nolan \& Marginson 1990, Metcalf 2002). Our concern is that in an arena, such as local government, where there are strong formal procedures and robust commitments to equality and dignity at work, there can still be failings in the workplace with regard to implementation and sustained corporate watchfulness (Bach and Stroleny 2014; Yousef 2017).

Unions themselves are clearer about the importance of their role and their shortcomings. The TUC was concerned with problems of under-representation of members from a BAME background (TUC $2014 \mathrm{p} 3$ ). This is seen as a gap that may indicate a failure of policy making with regard to BAME workers' views of workplace unionism. Holgate $(2004 \mathrm{~b}, \mathrm{p} .1)$ raised the concern of lack of understanding BAME workers and their relationship with trade unions. She advocated 'community unionism' as one way of bringing more ethnically diverse workers into trade unions (Holgate 2005, 2015). Despite both the legislation and the wide acceptance of the arguments underpinning the 1976 Act and Code, in 1996 UNISON still felt it necessary to produce a pamphlet, Racial Harassment? It's not part of the job! In which the union urged those involved (in this case in the NHS) to change their 'culture'. The suggestion is twofold: first that left alone line managers do not implement race equality policies however rational and well-intentioned; and secondly, that union representatives have to be vigilant in the workplace to ensure policies are enforced.

We, in turn, take up this point about robust anti-racism in practice at work when enforced by active union pressure. This matters since the TUC reported that "there is still a widespread reluctance amongst Black workers to report incidents of racism and race discrimination to their union. The reasons for this are complex but a fear of being disbelieved or of being accused of "playing the race card' are significant factors" (TUC Black Workers Conference report 2015a, p.7). Our study proposes that unions are a major power at work which can transform the work experiences of BAME staff through their attitudes, not to the union per se, but to the environment created by management for their job satisfaction and perceptions of equity in which the unions play a major sustaining role.

Hypothesis 4: The relationship between BAME staff and equal work environment is moderated by the extent of the dedication of trade unions to equality matters, such that the negative perception is reduced under a high level of trade union endeavour towards equality

In summary, we hypothesize that BAME employees working in local government have a lower evaluation on fair pay and job satisfaction due to the persistence of racism at the workplace, but that such negative perceptions can be reduced when management is seen to make efforts to maintain an equal work environment. Furthermore, we examine whether the association between BAME 
employees and perceived equal work environment is strengthened by trade union's commitment to equality. Figure 1 and 2 depict the hypothesised relationships in the present study.

Figure $1 \& 2$ about here

\section{Methods}

\section{Data collection and participant characteristics}

The data came from a stratified survey of five local authorities (two in London, two in the Midlands, and one in the North of England), and was funded by UNISON. They were chosen both for accessibility and having a higher than the national average proportion of BAME employees. The survey covered all workers in particular parts of these five authorities and was further stratified by department - social care, housing, and education where there are larger numbers of BAME staff. 2,583 valid responses were retained from 15,000 questionnaires sent, constituting a response rate of $17 \%$.

The sample comprised 29\% ethnic minorities (Black, 10\%; Asian, 15\%; mixed and other makes up, $4 \%$ ); almost one third, $31 \%$, are male employees; the average age is 44 years (range from 17 to 71 ) and the average job tenure is 11years. The majority of these responses are on a permanent contract (92\%) and work full time (74\%). In addition, union members account for $71 \%$. The respondents represented a range of occupational backgrounds including professional or managers (52\%); administrators or technicians (17\%); and clerical or manual work (31\%).

\section{Measures}

All scale items were in the form of a statement followed by a five-point response range from 1 (strongly disagree) to 5 (strongly agree). To control for the influence of common method bias in the study, the established recommendation (Podsakoff, et al., 2003) was followed. The procedures were explained to all participants and anonymity was guaranteed. The research team ${ }^{2}$ addressed remedies to reduce evaluating apprehension, improving item wording and separating the measurement of the predictor and outcome variables as a wide range of questions were asked.

\section{Equality-committed trade unionism}

On the basis of three main functions of trade unions: representation, bargaining and campaigning (McCarthy, 1966), four items were used: trade unions challenge abusive managers, trade unions raise equality issues with the employer, trade unions challenge racist managers, and trade unions are against racism in society. Internal consistency was 0.90 .

\footnotetext{
${ }^{2}$ Mike Ironside, Kath Clark, and Roger Seifert
} 
Equal Work Environment (EWE) was established from the equality duty for the general public sector derived from the Equality Act 2010. Respondents were asked to rate these three items: management is good at preventing discrimination; management take complaints about bullying seriously; management take complaints about racism seriously. Internal consistency was 0.80 .

Perception of Fair Pay was derived from the Fair Pay Act 2005 (U.S.), reflecting equal pay for jobs that are comparable in skill, effort, responsibility, and working conditions (Giapponi \& McEvoy, 2005). It was measured by rating the following statements: my pay is fair compared to other council workers; I am fairly rewarded for the amount of effort required in my job; for the amount of skill required in my job; for the amount of responsibility involved in my job. Internal consistency was 0.80 .

Job satisfaction is based on intrinsic aspects of one's job, autonomy, initiative, achievement (Spector, 1997; Hirschfeld, 2000). This variable is measured by four items: I am free to decide how to do my job; I get a sense of achievement from my work; I can use my own initiative at work; management allows us to decide how to share out the work. Internal consistency was 0.72 .

Table 1 presents means and standard deviations for each scale, and inter-scale correlations for main variables. The correlations show the expected direction of association: managerial workers are positively correlated with job satisfaction; union members are negatively and significantly correlated with job satisfaction and perception of equal work environment, but positively correlated with perception of equality commitment of trade union activists. All correlations in Table 1 were below the 0.70, a Variance Inflation Factor (VIF) test shows the value is less than 2 (not exceeding the threshold value VIF $>4$ ), the potential likelihood of multicollinearity is not a concern (Tabachnick \& Fidell 1996).

Insert Tables 1 and 2 about here

\section{Preliminary analyses}

A series of tests were carried out to assess the validity of variables included. First, confirmatory factor analysis was conducted to establish the discriminant validity of the scales. A full measurement model with indicators loaded onto their respective construct was tested. Five fit indices were calculated after each model to determine model fit (Hair, Black, Babin, \& Anderson, 2009). According to Arbuckle (2006), the $\chi^{2} / \mathrm{df}$ value is less than 2.5 indicate a good fit and values around 5.0 an acceptable fit; the recommended value as an indication of good model of the comparative fit index (CFI) and normed fit index (NFI) is close to .95 (Bentler \& Bonett, 1980; Hair et al., 2009; Hu \& Bentler, 1999). For the root mean square error of approximation (RMSEA) and standardized root mean square residual (SRMR), values less than .06 indicate a good model fit and values less than .10 are an acceptable fit 
(Arbuckle, 2006; Browne \& Cudeck, 1993). The four-factor model showed a good model fit $\left(\chi^{2}=428\right.$; $\mathrm{df}=98, \mathrm{CFI}=0.96, \mathrm{NFI}=0.96, \mathrm{RMSEA}=0.04 ; \mathrm{SRMR}=0.03$ ), apart from the value of $\chi^{2} / \mathrm{df}$. Since the $\chi^{2} / \mathrm{df}$ value is very sensitive to large sample size (more than 200 ), and we have 2,580 responses, the value is acceptable (Hair et al. 2009; Schlermelleh-Engel et al. 2003).

Second, sequential $\chi^{2}$ difference tests were carried out to decide between competing models. The full measurement model was compared to three alternative nested models. Alternative model A subsumed fair pay and job satisfaction under one factor. As shown in Table 2, the model fit decreased significantly, this evidenced the distinctness and construct validity of both measures. We also subsumed equal work environment and equality perception of union effort under one factor in model $\mathrm{B}$; and equal work environment and fair pay in Model $\mathrm{C}$, none of them provides a good model fit. Therefore, all constructs in the model were distinct from one another.

In order to decide using a traditional structural equation model to test the hypotheses instead of a multilevel structural equation model, Intraclass Correlation Coefficient (ICC) value was calculated to identify whether there is sufficient variance across these five local governments. All value is less than 0.02 , which indicates group membership has very little influence on employees' evaluation, therefore the group variance is very small and traditional structural equation model is more appropriate (Hox et al. 2010).

\section{Test of hypotheses}

STATA 13 was used to run mediation following the steps outlined by Baron and Kenny (1986) to test hypotheses 1-3, and an OLS regression moderated mediation model to test hypotheses 4 followed steps outlined by Preacher et al. (2007) and Hayes (2013). In all analysis, we included gender, age, type of contract, occupation, and union membership status. The main independent variables were standardised in all analyses in order to construct the interaction item and to reduce the likelihood of multi-collinearity (Aiken and West 1991), and the dependent variable was un-standardised.

Insert tables 3 and 4 about here

Results in Table 3 indicate that BAME employees are negatively and significantly correlated with the perception of fair pay but there is no significant difference in terms of intrinsic job satisfaction when controlled for gender, age, occupation, job tenure, type of contract, working full time and union member. This leads support to hypothesis 1 a but not hypothesis $1 \mathrm{~b}$. Results in Table 3 further reveal that BAME employees are negatively and significantly related to perception of equal work environment, this supports hypothesis 2 .

Furthermore, an equal work environment is significantly and positively correlated with perception of fair pay and job satisfaction. When both BAME staff and equal work environment are entered into the 
fair pay model simultaneously, the coefficient of BAME drops in significance, indicating that equal work environment fully mediates the relationship between BAME and the perception of fair pay. Sobel's test (1982) shows the ratio of indirect effect is $57 \%$ and the intervening effect of equal work environment on the relationship between BAME and perception of fair pay was significant (Sobel test statistics: $-6.71, \mathrm{p}<0.001)$. Therefore hypothesis $3 \mathrm{a}$ is supported but not hypothesis $3 \mathrm{~b}$. Although the $\mathrm{R}$-squared value (0.07) is relatively low, it is similar to prior research, indicating that explanations of fair pay are likely to be highly complex (Dickinson and Sell-Trujillo, 2016). Typically this is associated with the widely recognised pay gap based on ethnicity (Bulman and Musaddique 2018) and under representative of BAME in senior positions (Chowdhury 2016; McGregor-Smith 2017).

It is interesting to see in Table 3, when both BAME staff and equal work environment are included in the job satisfaction model, BAME staff become positively and significantly correlated with job satisfaction. That is to say, with the same level of equal work environment, BAME employees have a significantly higher level of job satisfaction than their white colleagues. Sobel's test (1982) shows that the direct effect $(\mathrm{a}=0.15, \mathrm{p}<0.001)$ was counteracted by perceived lower endeavour by management to prevent bullying, discrimination, and racism $(b=-0.14, p<0.001)$. Therefore the overall evaluation of job satisfaction was eroded (total effect $=0.01, p=n . a$.), this partially explains hypothesis $1 \mathrm{~b}$ and $3 \mathrm{~b}$

Hypothesis 4 predicts that the relationship between BAME employees and perceived equal work environment would be moderated by the perception of trade union commitment to equality at work, as shown in Table 4, the negative perception of equal work environment by BAME staff is significantly moderated by their perception of trade union committed to equality. This has been further demonstrated in Figure 3, the gap in perceived equal work environment between BAME employees and their white colleagues are statistically significant $(b=-0.43, p<0.001)$ at low levels of perceived trade union commitment, but become moderate in higher levels of trade union commitment $(b=-0.31$, $\mathrm{p}<0.001)$. This indicates that the extent of adverse perception of management endeavour depends on the level of trade union commitment to equality, and is less an issue with highly perceived trade union commitment. Our hypothesis 4 is supported.

Insert Figure 3 about here

\section{Discussion}

Our survey sought to test four logically and empirically related statements. These were that, ceteris paribus, BAME staff feel unfairly paid and have lower job satisfaction; that such sentiments can be influenced by the extent to which they perceive there is an equal work environment; and that such an equal work environment can be strengthened by the behaviour of the trade union. As with all workplace studies the argument is made that effective trade unionism can reduce both the reality and 
the sense of alienation and exploitation brought about by the power imbalance as between employer and employee (Smith, Smith, and Ackers 1996).

As Miller (2017) stated large employers, especially in the state sector, will have in place robust and verifiable equal opportunities policies based both on current legislative and regulatory frameworks and in line with best HRM practices The need for research is that such policies and procedures only become active and relevant in the workplace if, and only if, line managers implement and/or support its implementation. The problem remains that it is difficult to measure such practices in action and to have a sense that implementation is effective. This becomes more interesting as well as more difficult when the reason for line managers equal opportunities zeal is rooted in trade union pressures and activities.

Asking both 'white' and BAME colleagues working in the same workplace about these matters seemed the reliable way to lead to useful findings. Our findings show that a strong commitment to equality by trade unions shown by challenges to abusive managers, by raising equality issues with the employer, by exposing racist managers, and through campaigns against racism in society, together can push managers to a better application of equality practices. And that a positive view of trade union role in creating and sustaining equality at work is a major factor in the working lives of BAME staff. Indeed the latest figures for trade union membership in the UK show that Black or Black British ethnic group have a density of $26.4 \%$ compared with $23.8 \%$ for White ethnic (2016 Department for Business, Energy \& Industrial Strategy, p.9). Further analysis by sector, size of the enterprise, occupation, age, and region shows some variation around these averages, but the main trends are clear - BAME workers are, ceteris paribus, as likely as white workers to belong to a trade union in the UK in 2016.

Overall our findings show that BAME workers do feel unfairly paid but this has the least impact on their job satisfaction, which may be an indication of their strong public service motivation (Lewis and Frank 2002). More importantly, a robust equal work environment as perceived by BAME staff is a major factor in both boosting their job satisfaction and an acceptance of relatively 'unfair' low pay. This is not an inert passive acceptance of their work experience but based on the actual role of line managers in the pro-active prevention of bullying and racial discrimination. In turn, this is strengthened when the trade union is seen actively to ensure equality through 'shocking' managers into being better at enforcement of equality rules in the workplace. We have noted that BAME workers attachment to unionism is the same as their white colleagues overall, but that they remain under-represented in terms of union activists and officials. One familiar reason for this mismatch is the extent to which any historically disadvantaged group feel that the union takes up the struggle on their behalf - the more actively union representatives on the ground fight for equality in the 
workplace, and are seen to so fight, the more support the union receives, both active and passive, from the members of that group (Kelly and Willman 2004).

\section{Practical implication}

Trade unions as organisations and trade unionists have not been immune from both racial stereotyping and racism. This at one level clearly goes against the origins and purposes of trade unionism itself in their role as the 'sword of justice' (Flanders 1970; Metcalf, Hansen, and Charlwood 2001). All mainstream UK unions today have robust anti-racist and anti-racism policies and programmes. A recent post on the UNISON website asked: "Have you experienced racism at work? It is one of the priorities of UNISON, and other unions, to protect members from discrimination and everyday racism - but still, too many Black workers have been the target of workplace racism" (20 January 2017). A recent TUC report (2017) started by noting that: "Trade unions have a long history of opposing racism and discrimination in the workplace. In recent years, though, the debate has narrowed to focus only on access to work. This has obscured the daily reality of racism at work for many BME workers - and has reduced the focus on stopping it ... This report clearly shows that racial harassment still goes on in too many workplaces" (p.3). A recent CIPD survey as reported in People Management (4/12/17) found that 'BAME employees were twice as likely to say that discrimination holds back their careers'. Our study provides evidence of such discrimination, but more importantly, illustrates the importance of positive attitudes to union interventions.

This also has implications for union workplace strength and ultimately on their collective bargaining powers (Ewing, Hendy and Jones 2016) as it appears to re-assert positive 'boots on-the-ground' trade unionism. In this sense it can be as useful a recruiting and sustaining mechanism as strike action (Hodder et al. 2017), but with longer-term and more realistic potential as a permanent basis for union recognition and progression. Our evidence shows that even when support for the union is in some sense 'indirect' since it comes through pressure on management, and that this changed management behaviour is what is valued by BAME staff, nonetheless the role of the union is understood as being essential to the process of improved equality management.

As the UK workforce becomes more diverse and as equality issues become more relevant and are no longer 'hidden in plain sight' (Dawson 2016), so the role for workplace union representatives to be the front line against discrimination in all its forms becomes greater. As the TUC and some unions are aware this is now increasingly urgent as racist voices are being raised with more confidence outside the workplace, and as relatively low pay means that non-pay elements of being at work loom larger in the minds of most staff. This suggests that BAME sections of unions might well be re-integrated into the mainstream of union concerns as an awareness of the issues, representative training across the board, and tackling management in an uneven power relationship becomes the hallmark of what a trade union is and what it is for. 


\section{Conclusion}

This paper illustrates the importance of strong union activity in the realm of workplace equality with the focus on experiences of BAME staff in the public sector. We found that a positive set of attitudes by BAME workers towards the union role in promoting and protecting anti-racist behaviours carried with it a stronger willingness to accept negative aspects of working in local government, such as lower pay and increased job satisfaction. In other words BAME staff highly valued a decent equality working environment and which subsequently alleviated their perception of lower pay and increased their job satisfaction. This was linked to their survey responses to managers taking more care over relevant equality issues, which was seen subject to active union pressure. Therefore union activity to ensure equality in the public sector also seems one way to address the recruitment and retention challenge in this sector under the current economic climate.

\section{References}

ACAS (2006) Back to basics. Acas' experience of equality and diversity in the workplace, London:

ACAS (2014) Trade Union Representation at the Workplace, London: ACAS

Aiken, L.S., and West, S.G. (1991), Multiple Regression: Testing and Interpreting Interactions, Newbury Park, CA: Sage

Arbuckle, J. L. (2006). Amos (version 7.0) [computer program]. Chicago, IL: SPSS.

Archibong, U. and Darr, A. (2010) 'The Involvement of Black and Minority Ethnic Staff in NHS Disciplinary Proceedings'. A report of research carried out by the Centre for Inclusion and Diversity, University of Bradford on behalf of NHS Employers and NHS Institute for Innovation and Improvement

Bach, S. and Stroleny, A., (2014). 'Restructuring UK local government employment relations: pay determination and employee participation in tough times'. European Review of Labour and Research, 20(3): 343-356.

Bentler, P. M., \& Bonett, D. G. (1980). 'Significance tests and goodness of $\mathrm{fi} t$ in the analysis of covariance structures'. Psychological Bulletin, 88: 588-606.Brent \&Kilburn Times (22/09/2014). 'Brent Council found guilty of victimisation and racism against black worker', available at http://www.kilburntimes.co.uk/news/politics/brent-council-found-guilty-of-victimisation-and-racismagainst-black-worker-1-3779365

Browne, M.W., and Cudeck, R. (1993), 'Alternative Ways of Assessing Model Fit,' in Testing Structural Equation Models, eds. K.A. Bollen and J.S. Long, Newbury Park, CA: Sage: 136-162. 
Bulman. M., and Musaddique. S., 2018. Black, Asian and ethnic minority public sector workers in London paid up to $37.5 \%$ less than white colleagues, The Independent, 2 March 2018, Available at: http://www.independent.co.uk/news/business/news/sadiq-khan-ethnic-pay-gap-london-public-sectortroubling-gla-a8236481.html. Access on $9^{\text {th }}$ March 2018

Charness, G. and Kuhn, P., (2007). 'Does pay inequality affect worker effort? Experimental evidence'. Journal of labor economics, 25(4): 693-723.

Chowdhury, A. (2016), I can't say I am shocked that $96 \%$ of public sector leaders are white, The Guardian (7 May 2016). Accessed on $14^{\text {th }}$ Nov.2016. URL: https://www.theguardian.com/publicleaders-network/2016/may/07/public-sector-leaders-white-civil-service-bme.

Chynoweth, C. (2015), 'The public sector faces terrifying challenges', People Management, 23 Sept. 2015. Accessed on 22nd June 2017.

Dawson, M.C., (2016). 'Hidden in Plain Sight: A Note on Legitimation Crises and the Racial Order'. Critical Historical Studies, 3(1): 143-161.

Dickens, L., (2007). 'The road is long: thirty years of equality legislation in Britain'. British Journal of Industrial Relations, 45(3): 463-494.

Dickinson, J., \& Sell-Trujillo, L. (2016). 8 Fair Pay and Pay. Choice and Public Policy: The Limits to Welfare Markets,Ed P. Taylor-Gooby. 145-161.Macmillian Press LTD, London

Equality Challenge Unit (2009) The experience of black and minority ethnic staff working in higher education: Literature review.

EqualPayPortal, (2017). Law. Available at http://www.equalpayportal.co.uk/the-law

Ewing, K., Hendy, J. and Jones, C. (2016) A Manifesto for Labour Law, Liverpool: Institute of Employment Rights

Fevre, R. (1985). 'Racial discrimination and competition in British trade unions'. Ethnic and Racial Studies, 8(4): 563-580.

Fitzgerald, I., \& Stirling, J. (2004). 'Black Minority Ethnic Groups Views of Trade Unions in Newcastle' TUC: Northern Region.

Flanders, A. (1970) Management and Unions, London; Faber \& Faber

Giapponi, C. C., \& McEvoy, S. A. (2005). 'The legal, ethical, and strategic implications of gender discrimination in compensation: Can the Fair Pay Act succeed where the Equal Pay Act has failed?' Journal of Individual Employment Rights, 12(2):137-150 
Hair, J. F., Black, W. C., Babin, B. J., \& Anderson, R. E. (2009). Multivariate data analysis, NJ: Pearson Prentice Hall.

Harrington, S., Rayner, C., \& Warren, S. (2012). 'Too hot to handle? Trust and human resource practitioners' implementation of anti-bullying policy. Human Resource Management Journal, 22(4), $392-408$.

Hayes, A. F. (2013). An introduction to mediation, moderation, and conditional process analysis. New York: Guilford Press Hirschfeld, R.R. (2000). 'Validity studies. Does revising the intrinsic and extrinsic subscales of the Minnesota Satisfaction Questionnaire Short Form make a difference?' Educational Psychological Measurement, 60: 255-270.

Hirschfeld $2000 * * * *$

Hodder, A., Williams, M., Kelly, J. and McCarthy, N., (2017). 'Does strike action stimulate trade union membership growth?' British Journal of Industrial Relations, 55(1):165-186.

Hodson, R., (2001). Dignity at work. Cambridge: Cambridge University Press.

Hoel, H. (2013). Workplace Bullying in United Kingdom. Workplace Bullying and Harassment, JILPT Report, No 2, P61.

Holgate, J. (2004a) 'The influence of race, identity and community in union organising in west London', Paper presented to 54th British Universities Industrial Relations Annual Conference. University of Nottingham

Holgate, J. (2004b). Black and minority ethnic workers and trade unions: Strategies for organisation, recruitment and inclusion. Queen Mary, University of London.

Holgate, J. (2005). 'Organizing migrant workers: a case study of working conditions and unionization in a London sandwich factory'. Work, employment and society, 19(3): 463-480.

Holgate, J. (2015). 'Community organising in the UK: A 'new'approach for trade unions?' Economic and Industrial Democracy, 36(3): 431-455.

Hox, J. J., Moerbeek, M., and Van de Schoot, R. (2010). Multilevel analysis: Techniques and applications. $2^{\text {nd }}$ edition. (pp.288-309). Routledge. NY.

Hu, L., and Bentler, P.M. (1998), 'Fit Indices in Covariance Structure Modeling: Sensitivity to Underparameterized Model Misspecification,'P Psychological Methods, 3: 424-453. 
Humphrey, J. C. (2000). 'Self-organization and trade union democracy'. The Sociological Review, 48(2): 262-282.

Hyman, R., (1994). Theory and industrial relations. British Journal of Industrial Relations, 32(2): 165-180.

Jefferys, S., (2015). The context to challenging discrimination against ethnic minorities and migrant workers at work. Transfer: European Review of Labour and Research, 21(1): 9-22.

Kelly, J. and Willman, P. (2004) Union organization and activity, London: Routledge

Lewis, G. B., \& Frank, S. A. (2002). 'Who wants to work for the government?'. Public administration review, 62(4), 395-404.

Lewis, D., \& Gunn, R. O. D. (2007). Workplace bullying in the public sector: Understanding the racial dimension. Public Administration, 85(3): 641-665.

Lucio, M. M., \& Perrett, R. (2009). 'The diversity and politics of trade unions' responses to minority ethnic and migrant workers: The context of the UK'. Economic and Industrial Democracy, 30(3): 324-347.

McCarthy, W.E.J., (1966). The Role of Shop Stewards in British Industrial Relations, Research Paper 1, Royal Commission on Trade Unions and Employers' Associations

McGregor-Smith Review (2017): Race in the workplace. Gov.UK. Available at https://www.gov.uk/government/publications/race-in-the-workplace-the-mcgregor-smith-review Mefford, R. N. (1986). 'The effect of unions on productivity in a multinational manufacturing firm'. ILR Review, 40(1): 105-114.

Metcalf, D. (2002). Unions and productivity, financial performance and investment: international evidence. Centre for Economic Performance, London School of Economics and Political Science.

Metcalf, D., Hansen, K. and Charlwood, A., (2001). 'Unions and the sword of justice: unions and pay systems, pay inequality, pay discrimination and low pay'. National Institute Economic Review, 176(1): 61-75.

Miles, R., \& Phizacklea, A. (1978). 'The TUC and black workers 1974-1976'. British Journal of Industrial Relations, 16(2): 195-207.

Miller, J. (2017) Real change on racial equality at work requires more action, CIPD Voice Issue 9 
Nolan, P. \& Marginson, P. (1990). 'Skating on thin ice? David Metcalf on trade unions and productivity'. British Journal of Industrial Relations, 28(2): 227-247.

Owoyemi, O. A., \& Sheehan, M. (2011). Exploring Workplace bullying in an Emergency Service Organisation in the UK. International Journal of Business and Management, 6(3): 63-80.

Pate, J., Morgan-Thomas, A., \& Beaumont, P. (2012). 'Trust restoration: An examination of senior managers' attempt to rebuild employee trust'. Human Resource Management Journal, 22(2), 148-164.

Podsakoff, P. M., MacKenzie, S. B., Lee, J. Y., \& Podsakoff, N. P. (2003). 'Common method biases in behavioral research: a critical review of the literature and recommended remedies'. Journal of applied psychology, 88(5): 879-903

Preacher, K. J., Rucker, D. D., \& Hayes, A. F. (2007). 'Addressing moderated mediation hypotheses: Theory, methods, and prescriptions'. Multivariate behavioral research, 42(1): 185-227.

Schermelleh-Engel, K., Moosbrugger, H., \& Müller, H. (2003). 'Evaluating the fit of structural equation models: Tests of significance and descriptive goodness-of-fit measures'. Methods of psychological research online, 8(2): 23-74.

Smith, P., Smith, P. and Ackers, P. eds., (1996). The new workplace and trade unionism. London: Routledge.

Sobel, M. E. (1982). 'Asymptotic confidence intervals for indirect effects in structural equation models'. In S. Leinhardt (Ed.), Sociological methodology (pp. 290-312). Washington, DC: American Sociological Association.

Spector, P. (1997). Job satisfaction: Application, assessment, causes, and consequences. London: Sage

Tabachnick, B.G., and Fidell, L.S. (1996), Using Multivariate Statistics, New York: HarperCollins.

TUC (2014) Equality Audit, London: TUC

TUC (2015a) Report of TUC Black Workers Conference, London: TUC

TUC (2015b) Living on the margins: black workers and casualization. London: TUC

TUC (2017) Let's talk about racism An interim report about the experiences of Black and minority ethnic workers in the workplace. London: TUC

UNISON (2009) Workplace Bullying and Harassment in 2009: Report to UNISON. London: UNISON. 
Verma, A. (2005). 'What do unions do to the workplace? Union effects on management and HRM policies'. Journal of Labor Research, 26(3): 415-449.

Virdee, S., \& Grint, K. (1994). 'Black self - organization in trade unions'. The Sociological Review, 42(2): 202-226.

Virdee, S. (2000). 'A Marxist critique of black radical theories of trade-union racism'. Sociology, 34(3): 545-565.

Virdee, S. (2006). ' Race', employment and social change: a critique of current orthodoxies'. Ethnic and Racial Studies, 29(4): 605-628.

Wrench, J. (1986) 'Unequal comrades: trade unions, equal opportunity and racism', Policy Papers in Ethnic Relations No.5 Centre for Research in Ethnic Relations, University of Warwick

Wrench, J. (2000). British unions and racism: organisational dilemmas in an unsympathetic climate. Trade Unions, Immigration, and Immigrants in Europe, 1960-1993: a Comparative Study of the Attitudes and Actions of Trade Unions in Seven West European Countries, 133-156.

Wood, S., Braeken, J., \& Niven, K. (2013). Discrimination and well-being in organizations: Testing the differential power and organizational justice theories of workplace aggression. Journal of business ethics, 115(3), 617-634.

Yousef, D.A., (2017). 'Organizational Commitment, Job Satisfaction and Attitudes toward Organizational Change: A Study in the Local Government'. International Journal of Public Administration, 40(1): 77-88. 
Tables

Table 1 Descriptive statistics, Correlation and scale reliability for variables

\begin{tabular}{|c|c|c|c|c|c|c|c|c|c|c|c|c|c|c|c|}
\hline & Variables & Alpha & Mean & S.D. & 1 & 2 & 3 & 4 & 5 & 6 & 7 & 8 & 9 & 10 & 11 \\
\hline 1 & Gender & & 0.31 & 0.46 & 1 & & & & & & & & & & \\
\hline 2 & Age & & 44.06 & 10.11 & $0.04 *$ & 1 & & & & & & & & & \\
\hline 3 & Permanent contract & & 0.92 & 0.26 & -0.00 & $0.12 * *$ & 1 & & & & & & & & \\
\hline 4 & Job tenure & & 11.28 & 6.74 & 0.00 & $0.42 * *$ & $0.25 * *$ & 1 & & & & & & & \\
\hline 5 & Work full time & & 0.73 & 0.44 & $0.24 * *$ & $-0.08 * *$ & 0.02 & -0.01 & 1 & & & & & & \\
\hline 6 & Managerial or professional & & 0.52 & 0.50 & 0.03 & -0.03 & -0.02 & 0.00 & $0.17 * *$ & 1 & & & & & \\
\hline 7 & Union membership & & 0.71 & 0.45 & $-0.06^{* *}$ & $0.16 * *$ & $0.23 * *$ & $0.35 * *$ & -0.01 & 0.04 & 1 & & & & \\
\hline 8 & BAME & & 0.29 & 0.45 & 0.01 & $-0.18^{* *}$ & $-0.06 * *$ & $-0.08 * *$ & $0.08 * *$ & -0.00 & $-0.07 * *$ & 1 & & & \\
\hline 9 & Perception of fair pay & 0.91 & 2.88 & 0.94 & $-0.11 * *$ & -0.00 & -0.00 & -0.03 & $-0.09 * *$ & 0.01 & -0.00 & $-0.08 * *$ & 1 & & \\
\hline 10 & Job satisfaction & 0.72 & 3.52 & 0.72 & $-0.05^{* *}$ & 0.02 & -0.01 & 0.01 & 0.00 & $0.11 * *$ & $-0.08 * *$ & -0.00 & $0.19 * *$ & 1 & \\
\hline 11 & Equal Work Environment & 0.84 & 3.37 & 0.85 & -0.02 & 0.02 & -0.02 & $-0.08 * *$ & $-0.07 * *$ & 0.01 & $-0.13^{* *}$ & $-0.19 * *$ & $0.25 * *$ & $0.40 * *$ & 1 \\
\hline 12 & Equality-committed trade unionism & 0.90 & 2.78 & 1.47 & $0.08 * *$ & $0.18 * *$ & $0.12 * *$ & $0.24 * *$ & 0.01 & $0.05^{* *}$ & $0.35 * *$ & $-0.04 *$ & $0.05^{*}$ & 0.02 & 0.00 \\
\hline
\end{tabular}

Note: $\mathrm{n}=2580 ; * \mathrm{p}<0.05 ; * * \mathrm{p}<0.01$ 
Table 2 measurement model comparisons

\begin{tabular}{llllllll}
\hline Models & $\mathrm{X}^{2}(\mathrm{df})$ & TLI & CFI & RMSEA & SRMR & $\mathrm{X}_{\text {diff }}^{2}$ & $\mathrm{df}_{\text {diff }}$ \\
\hline Full & $427.78(98)$ & 0.97 & 0.97 & 0.04 & 0.03 & & \\
measurement & & & & & & \\
Model & & & & & & \\
Model A & 1952(101) & 0.81 & 0.84 & 0.11 & 0.11 & 3 & 1525 \\
Model B & 2087(101) & 0.80 & 0.83 & 0.11 & 0.09 & 3 & 1660 \\
Model C & 2204(101) & 0.78 & 0.82 & 0.12 & 0.11 & 3 & 1776 \\
\hline
\end{tabular}

Note: Model A. Job satisfaction and fair pay combined into a single factor

Model B. Equal work environment and equality dedication of trade union combined into a single factor

Model C. Equal work environment and fair pay combined into a single factor 
Table 3 Regression Results for Testing Mediation

\begin{tabular}{|c|c|c|c|c|c|c|c|}
\hline & \multicolumn{4}{|c|}{ Perception of fair pay } & \multicolumn{3}{|l|}{ Job satisfaction } \\
\hline & $\begin{array}{l}\text { Equal work } \\
\text { environment }\end{array}$ & Step 1 & Step 2 & Step 3 & Step 1 & Step 2 & Step 3 \\
\hline Male & $-0.03(0.04)$ & $-0.18 * * *(0.04)$ & $-0.15 * * *(0.04)$ & $-0.15 * * *(0.04)$ & $-0.11 * * *(0.03)$ & $-0.10 * * *(0.03)$ & $-0.10 * * *(0.03)$ \\
\hline Age (years) & $0.02(0.02)$ & $0.00(0.00)$ & $0.04 *(0.00)$ & $0.04 *(0.02)$ & $0.03(0.00)$ & $0.01(0.00)$ & $0.03 *(0.00)$ \\
\hline Permanent contract & $0.02(0.07)$ & $-0.06(0.09)$ & $-0.08(0.09)$ & $-0.08(0.09)$ & $-0.00(0.06)$ & $-0.00(0.06)$ & $0.01(0.06)$ \\
\hline Job tenure & $-0.04 * *(0.02)$ & $-0.04(0.02)$ & $-0.03(0.02)$ & $-0.04(0.02)$ & $0.02(0.02)$ & $0.02(0.02)$ & $0.02(0.02)$ \\
\hline Full timer & $-0.08 *(0.05)$ & $-0.14 * * *(0.05)$ & $-0.13 * *(0.05)$ & $-0.13 * *(0.05)$ & $-0.00(0.05)$ & $0.04(0.05)$ & $0.03(0.05)$ \\
\hline Professional and Managerial jobs & $0.00(0.04)$ & $0.06(0.04)$ & $0.05(0.05)$ & $0.05(0.05)$ & $0.19 * * *(0.04)$ & $0.20 * * *(0.04)$ & $0.21 * * *(0.04)$ \\
\hline Administrator & $-0.12 * *(0.05)$ & $0.06(0.06)$ & $0.10(0.06)$ & $0.11(0.07)$ & $0.04(0.04)$ & $0.11 * * *(0.04)$ & $0.11 * *(0.04)$ \\
\hline Union membership & $-0.24 * * *(0.04)$ & $-0.00(0.04)$ & $0.06(0.05)$ & $0.06(0.05)$ & $-0.18 * * *(0.03)$ & $-0.14 * * *(0.04)$ & $-0.14 * * *(0.04)$ \\
\hline BAME & $-0.38 * * *(0.04)$ & $-0.18 * * *(0.04)$ & & $-0.04(0.04)$ & $0.01(0.03)$ & & $0.15 * * *(0.03)$ \\
\hline Equal work environment & & & $0.22 * * *(0.02)$ & $0.22 * * *(0.02)$ & & $0.29 * * *(0.01)$ & $0.31 * * *(0.02)$ \\
\hline \multicolumn{8}{|l|}{ Sobel's test } \\
\hline $\begin{array}{l}\text { Indirect effect (BAME-Equal work } \\
\text { environment-Fair pay) }\end{array}$ & $-0.10 * * *(0.01)$ & & & & \multicolumn{2}{|c|}{$\begin{array}{l}\text { Indirect effect (BAME-Equal work } \\
\text { environment-Fair pay) }\end{array}$} & $-0.13 * * *(0.01)$ \\
\hline Direct effect (BAME->Fair pay) & $-0.07(0.05)$ & & & & \multicolumn{2}{|c|}{ Direct effect (BAME->Fair pay) } & $0.14 * * *(0.03)$ \\
\hline Total effect (BAME->Fair pay) & $-0.17 * * *(0.04)$ & & & & \multicolumn{2}{|c|}{ Total effect (BAME->Fair pay) } & $0.01(0.03)$ \\
\hline Total number of responses & 1940 & 2167 & 1798 & 1798 & 2321 & 1882 & 1882 \\
\hline R2(Adj. R2) & $0.07(0.07)$ & $0.02(0.02)$ & $0.07(0.07)$ & $0.07(0.07)$ & $0.03(0.03)$ & $18 \%$ & $0.19(0.19)$ \\
\hline
\end{tabular}


Table 4 The Moderating Effect of Equality-committed Trade Unisom on the relationship between BAME and Equal Work Environment

\begin{tabular}{llll}
\hline & Step 1 & Step 2 & Step 3 \\
\hline Male & $-0.04(0.04)$ & $-0.06(0.04)$ & $-0.06(0.04)$ \\
Age (years) & $0.05(0.02)$ & $-0.00(0.02)$ & $-0.00(0.02)$ \\
Permanent contract & $0.04(0.07)$ & $-0.08(0.09)$ & $-0.09(0.09)$ \\
Job tenure & $-0.05^{* *}(0.02)$ & $-0.00(0.02)$ & $-0.00(0.02)$ \\
Full timer & $-0.10^{*}(0.05)$ & $-0.03(0.05)$ & $-0.03(0.05)$ \\
Professional and Managerial jobs & $0.00(0.04)$ & $-0.03(0.05)$ & $-0.02(0.05)$ \\
Administrator & $-0.14^{* *}(0.05)$ & $-0.20^{* *}(0.08)$ & $-0.20^{* *}(0.08)$ \\
Union membership & $-0.24^{* * *}(0.04)$ & $-0.42^{* * *}(0.07)$ & $-0.41^{* * *}(0.07)$ \\
BAME & & $-0.42^{* * *}(0.05)$ & $-0.39^{* * *}(0.05)$ \\
Equality-committed trade unionism & & $0.29 * * *(0.03)$ & $0.21^{* * *}(0.03)$ \\
Equality-committed*BAME & & & $0.18^{* * *}(0.05)$ \\
Total number of responses & 1940 & 1418 & 1418 \\
R2(Adj. R2) & $0.03(0.03)$ & $0.14(0.13)$ & $0.15(0.14)$ \\
\hline
\end{tabular}

Note: ${ }^{*} \mathrm{p}<0.1 ; * * \mathrm{p}<0.05 ; * * * \mathrm{p}<0.01$ 
Figure 1 Hypothesized Relationships among BAME, Trade unionism committed to equality, Equal work environment and Fair pay

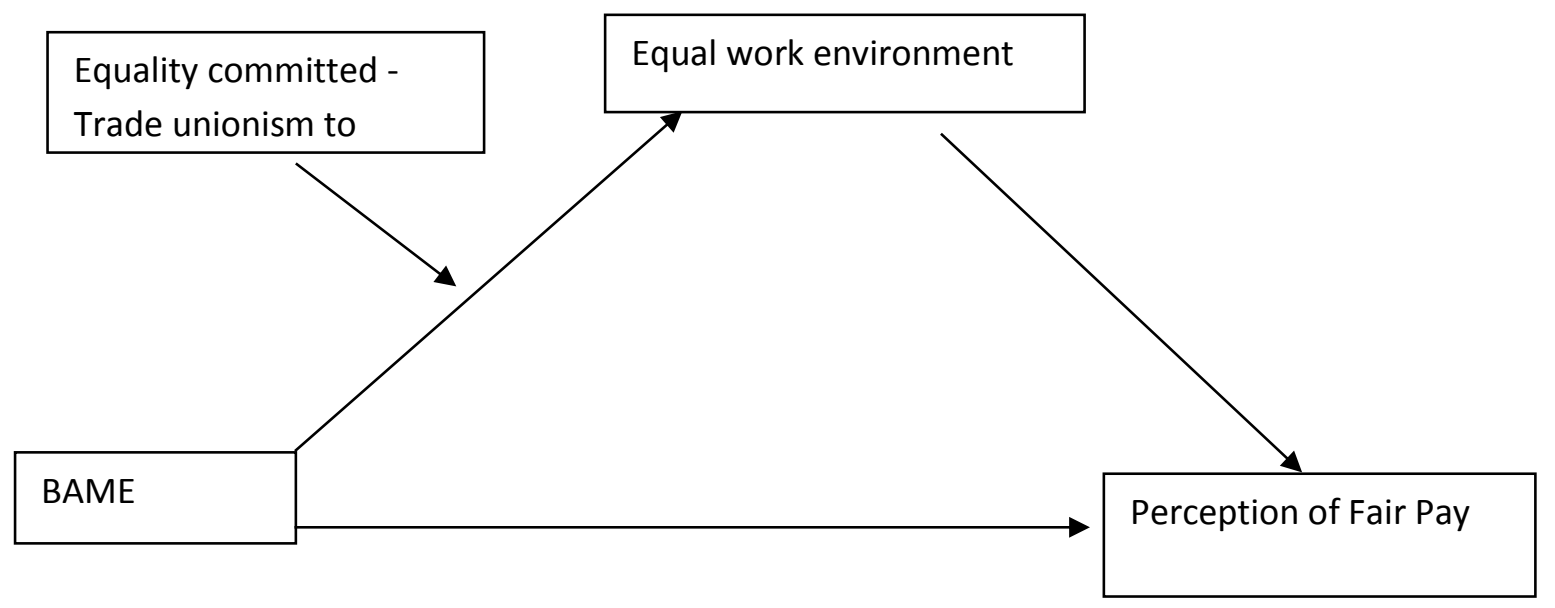

Figure 2 Hypothesized Relationships among BAME, Trade unionism committed to equality, Equal work environment and Job Satisfaction

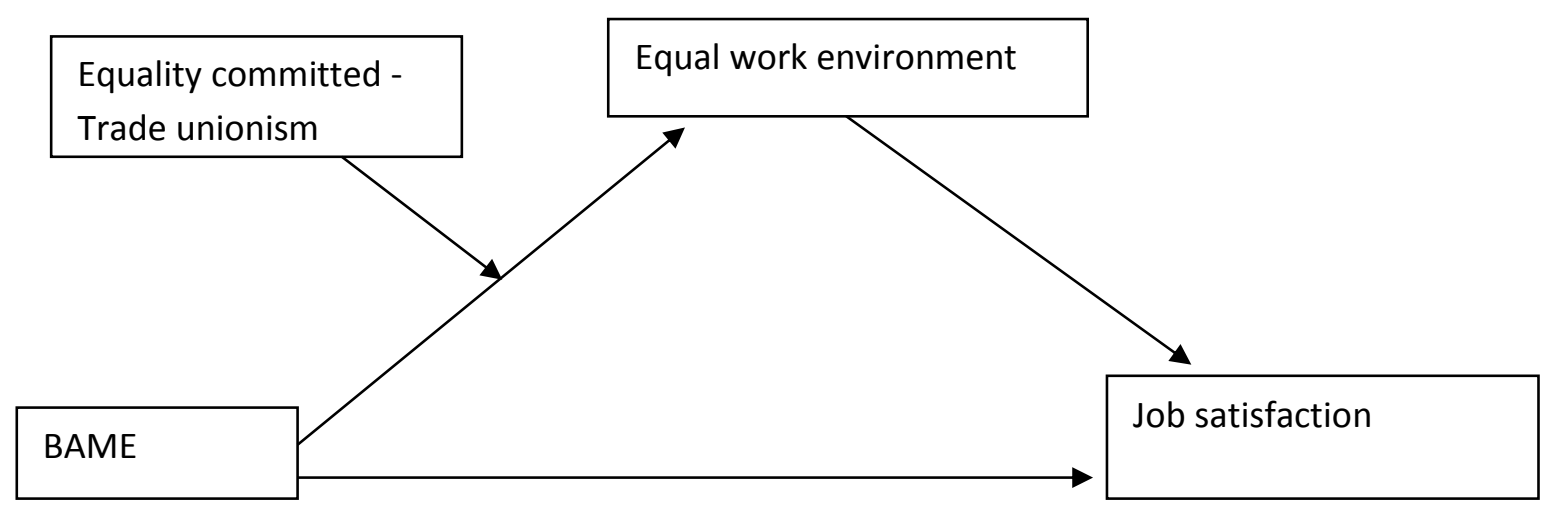


Figure 3 the moderating effect of Equality-committed trade union

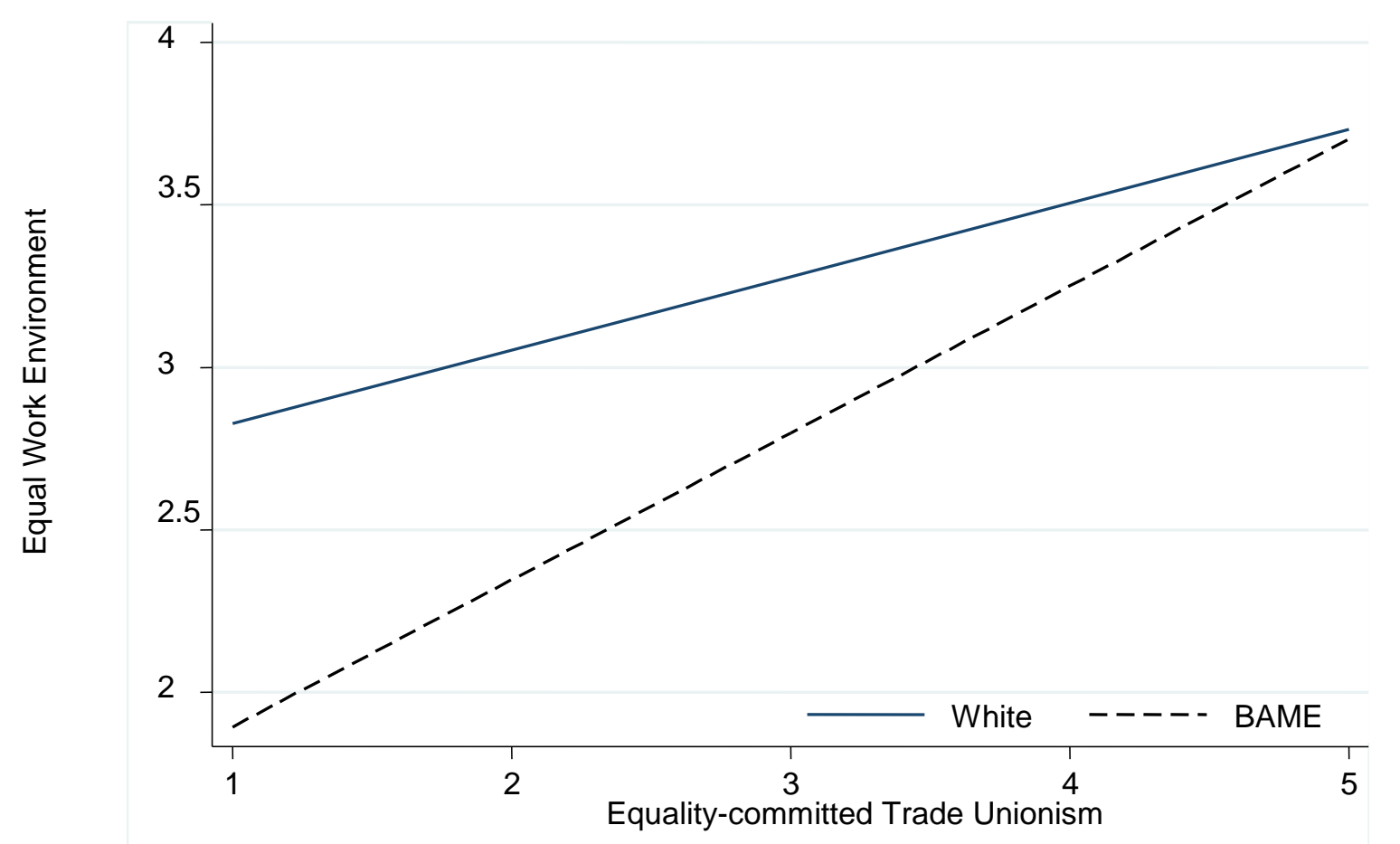


Appendix summary of measurement

\begin{tabular}{|c|c|c|c|c|c|}
\hline Variables ( $1=$ strongly disagree $; 5=$ strongly agree) & $\begin{array}{l}\text { Factor } \\
\text { loadin } \\
\text { gs }\end{array}$ & $\begin{array}{l}\text { Number of } \\
\text { responses }\end{array}$ & $\begin{array}{l}\text { BAME- } \\
\text { employee }\end{array}$ & $\begin{array}{l}\text { White- } \\
\text { employee }\end{array}$ & $\mid$ T-test $\mid$ \\
\hline \multicolumn{6}{|l|}{ Equality-committed Trade Unionism } \\
\hline They challenge abusive managers & 0.78 & 1944 & 3.48 & 3.60 & $2.59 * * *$ \\
\hline They raise equality issues with the employer & 0.80 & 2035 & 3.58 & 3.70 & $3.30 * * *$ \\
\hline They challenge racist managers & 0.83 & 1861 & 3.46 & 3.66 & $4.99 * * *$ \\
\hline They campaign against racism in society & 0.76 & 2015 & 3.57 & 3.74 & $4.36 * * *$ \\
\hline Cronbach's alpha & 0.90 & & & & \\
\hline \multicolumn{6}{|l|}{ Equal work environment } \\
\hline Management are good at preventing discrimination & 0.77 & 2360 & 2.91 & 3.30 & $9.06^{* * *}$ \\
\hline Management take complaints about bullying serious & 0.81 & 2210 & 3.14 & 3.33 & $3.88 * * *$ \\
\hline Management takes complaints about racism seriously & 0.75 & 2254 & 3.25 & 3.80 & $12.83 * * *$ \\
\hline Cronbach's alpha & 0.84 & & & & \\
\hline \multicolumn{6}{|l|}{ Perception of fair Pay } \\
\hline My pay is fair compared to other council workers & 0.77 & 2461 & 2.85 & 3.12 & $5.35 * * *$ \\
\hline I am fairly rewarded for the amount of effort required in my job & 0.92 & 2506 & 2.63 & 2.86 & $4.77 * * *$ \\
\hline I am fairly rewarded for the amount of skill required in my job & 0.93 & 2524 & 2.68 & 2.84 & $3.38 * * *$ \\
\hline $\begin{array}{l}\text { I am fairly rewarded for the amount of responsibility involved in } \\
\text { my job }\end{array}$ & 0.90 & 2519 & 2.60 & 2.74 & $3.04 * * *$ \\
\hline Cronbach's alpha & 0.91 & & & & \\
\hline Intrinsic job satisfaction (Cronbach's alpha) & 0.72 & & & & \\
\hline
\end{tabular}




\begin{tabular}{llllll}
\hline I am free to decide how to do my job & 0.64 & 2522 & 2.85 & 2.73 & $2.57^{* *}$ \\
I get a sense of achievement from my work & 0.53 & 2534 & 2.15 & 2.20 & 1.23 \\
I can use my own initiative at work & 0.80 & 2543 & 2.06 & 2.11 & 1.21 \\
Management allow us to decide how to share our the work & 0.57 & 2522 & 2.83 & 2.83 & 0.14 \\
\hline
\end{tabular}

Note: ${ }^{*} \mathrm{p}<0.5 ; * * \mathrm{p}<0.1 ; * * * \mathrm{p}<0.01$ 
